\section{Crop stimulants as a factor determining the yield and quality of winter wheat grown in Notec Valley, Poland}

\section{Tomasz Knapowski ${ }^{1, *}$, Bożena Barczak ${ }^{1}$, Wojciech Kozera ${ }^{1}$, Elżbieta Wszelaczyńska ${ }^{2}$ and Jarosław Pobereżny ${ }^{2}$}

${ }^{1}$ Department of Agricultural Chemistry, Faculty of Agriculture and Biotechnology, UTP University of Science and Technology, Seminaryjna 5 Str., 85-326 Bydgoszcz, Poland

${ }^{2}$ Department of Food Technology, Faculty of Agriculture and Biotechnology, UTP University of Science and Technology, Kordeckiego 20 Str., 85-225 Bydgoszcz, Poland

The application of stimulants to improve growth rate and quality of crops is gaining importance. Such preparations do not harm the environment and may partly supplement the action of nutrients applied. Therefore, during 2012-2014, a study was conducted to evaluate the performance of several stimulants: an amino acid preparation, liquid fertilizer biostimulant, seaweed extract, a multiple natural foliar nanofertilizer and their combinations on wheat grain yield and quality. The results indicated that these preparations strongly influenced grain yield and baking traits such as falling number, protein content, wet gluten, sedimentation value and bread volume. The best results were obtained on using multiple natural foliar nanofertilizer + amino acid preparation, with $20.1 \%$ higher yield in 2013 and $22.6 \%$ higher yield in 2014 in comparison with the control. The most favourable values of technological features were obtained with multiple natural foliar nanofertilizer in combination with amino acid preparation or seaweed extract. Wet gluten was the highest and the protein content and bread volume were high after spraying wheat with multiple natural foliar nanofertilizer and the next values of protein content and sedimentation resulted from the use of seaweed extract. The interest in nanofertilizers and preparations that stimulate plant growth and development is increasing constantly and it may become one of the essential elements of cultivation technology in future. Broadening the knowledge on bioregulators can result in an increase in the effectiveness of agricultural production as well as in the quality of crops.

Keywords: Grain yield, stimulants, technological parameters, Triticum aestivum L.

WHEAT grain and its flour are characterized by optimum values of baking traits, thus ensuring quality and technological process stability. These traits are determined genetically as well as by a host of environmental factors

*For correspondence. (e-mail: knap@utp.edu.pl) such as growing zone and prevailing climate during crop growth ${ }^{1-8}$. Application of plant nutrients through chemical fertilizers, particularly of nitrogen, to improve yield and quality is well known ${ }^{5,8-15}$. However, there is a demand for technologies which will lead to growing crops with better root systems, and nutrients uptake and use efficiency to overcome their lower availability in the soil both in organic and inorganic forms. The studies of cereal crops indicated that the use of biostimulants accelerated root and shoot growth. Also, higher levels of macronutrients and micronutrients were observed in these crops ${ }^{16-19}$. Biostimulants applied to plants, seeds or growing substrates in specific formulations modify physiological processes. Small amounts of these organic substances stimulate plant growth and development unrelated to nutrients $^{20,21}$. They also positively influence the stress response $^{22}$. Agricultural biostimulants can include microorganisms, trace elements, enzymes, plant growth regulators and seaweed extracts that are added to either crops or soil to improve the physiological processes in plants and boost their efficiency ${ }^{21,23,24}$. It has been reported that these preparations support the process of plants adapting to stressful conditions (both biotic and abiotic), and may increase metabolism and chlorophyll production ${ }^{21,25-29}$. According to Craigie ${ }^{24}$, and Matysiak and Adamczewski $^{26}$, the favourable effect of seaweeds on cultivated plants has been known in the regions where they are derived, and developing methods for obtaining durable extracts from them became the turning point in their application. Biostimulants contain many active agents such as growth hormones, auxins (acting on the formation of roots), cytokinins (regulating stem elongation), and polyamines and brassinosteroids (enhancing growth and development). The plant biomass and reproductive yields are improved by phytohormones contained in the extracts. The alginate, fucan and laminaran contained in marine algae preparations are essential for plants defence mechanisms against diseases and pests. Additionally, active substances of algal extracts in field crops can minimize the effect of drought stress, or $\mathrm{P}$ and $\mathrm{K}$ deficiency $^{21,30-33}$. Biostimulants may be applied alone or along with synthetic preparations and growth regulators ${ }^{25}$. They are used mainly on leaves and may be added to the plant multiple times during its growth period ${ }^{24}$. The results of biostimulants depend on the time of their application and the $\operatorname{dos}^{34}$. To optimize the wheat grain production intended for consumption, it is necessary to consider factors that improve its quality. It is expected that apart from fertilization (especially with nitrogen), application of preparations supporting plant growth will determine the yield quality. Consequently, this study aimed to evaluate the effect of stimulants (amino acid preparation, liquid fertilizer biostimulant, seaweed extract, multiple natural foliar nanofertilizer and their combinations) applied in winter wheat cultivation on the yield and values of some baking traits of grain and flour. 
Table 1. Chemical composition, dose and term of stimulants application

\begin{tabular}{|c|c|}
\hline Treatment (stimulant - commercial product name) & Chemical composition, dose and term of stimulants application $(* \mathrm{BBCH})$ \\
\hline Control object (C) & Without stimulants \\
\hline Amino acids preparation $(\mathrm{A})-$ Protaminal $^{\circledR}$ & $\mathrm{N}_{\text {tot }}-9.7 \%: \mathrm{NH}_{3}-4 \%, \mathrm{~N}_{\mathrm{org}}-2.9 \%$, urea nitrogen $-2.7 \%, \mathrm{SO}_{3}-6.7 \% ; 51 \mathrm{ha}^{-1}, * \mathrm{BBCH} 51$ \\
\hline $\begin{array}{l}\text { Liquid fertilizer biostimulative activecomplex } \\
\text { based on marine algae (B) - Fertileader } \\
\text { Vital-954 }\end{array}$ & 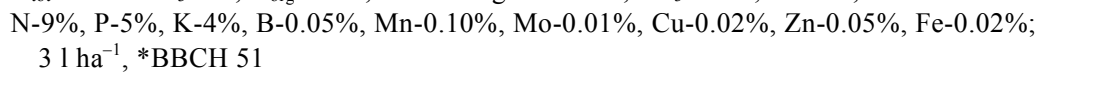 \\
\hline Seaweed extract (D) - Kelpak SL & Auxins $-11 \mathrm{mg} \mathrm{l}^{-1}$, cytokinins $-0.031 \mathrm{mg} \mathrm{l}^{-1} ; 21 \mathrm{ha}^{-1}, * \mathrm{BBCH} 28-30$ \\
\hline $\begin{array}{l}\text { Multiple natural foliar nanofertilizer }(\mathrm{E})- \\
\text { Nano-Active }\end{array}$ & $\begin{array}{l}\mathrm{CaO}-400, \mathrm{MgO}-40 \mathrm{~g} \mathrm{~kg}^{-1}, \mathrm{Fe}-1677, \mathrm{Mn}-139, \mathrm{Zn}-20, \mathrm{~B}-12, \mathrm{Cu}-6, \mathrm{Mo}-0.2, \mathrm{Na}_{2} \mathrm{O}-0.15 \mathrm{mg} \mathrm{kg}^{-1} ; \\
1,5 \mathrm{~kg} \mathrm{ha}^{-1},{ }^{*} \mathrm{BBCH} 28-30+1,5 \mathrm{~kg} \mathrm{ha}^{-1},{ }^{*} \mathrm{BBCH} 39\end{array}$ \\
\hline $\mathrm{E}+\mathrm{A}$ & $1,5 \mathrm{~kg} \mathrm{ha}^{-1}, * \mathrm{BBCH} 28-30(\mathrm{E})+51 \mathrm{ha}^{-1}, * \mathrm{BBCH} 51$ (A) \\
\hline $\mathrm{E}+\mathrm{D}$ & $1,5 \mathrm{~kg} \mathrm{ha}^{-1}, * \mathrm{BBCH} 28-30(\mathrm{E})+1,51 \mathrm{ha}^{-1}, * \mathrm{BBCH} 28-30$ (D) \\
\hline $\mathrm{D}+\mathrm{A}$ & $1.51 \mathrm{ha}^{-1}, * \mathrm{BBCH} 28-30$ (D) $+51 \mathrm{ha}^{-1}, * \mathrm{BBCH} 51$ (A) \\
\hline
\end{tabular}

*BBCH scale, Phenological development stages of cereals; $\mathrm{BBCH} 28-30$, End of tillering, beginning of stem elongation; *BBCH 39, Flag leaf stage: flag leaf fully unrolled, ligule just visible; ${ }^{*} \mathrm{BBCH} 51$, Beginning of heading: tip of inflorescence emerged from sheath, first spikelet just visible.

Table 2. Meteorological conditions during growing season of winter wheat

\begin{tabular}{lrrrrrr}
\hline & \multicolumn{3}{c}{ Growing season } & \multicolumn{2}{c}{$\begin{array}{c}\text { Long-period } \\
\text { average } \\
\end{array}$} & \multicolumn{3}{c}{$2012-2013$} & $2013-2014$ & \multicolumn{2}{c}{$(1949-2010)$} \\
\cline { 2 - 5 } Month & $\mathrm{mm}$ & \multicolumn{1}{c}{${ }^{\circ} \mathrm{C}$} & $\mathrm{mm}$ & ${ }^{\circ} \mathrm{C}$ & $\mathrm{mm}$ & ${ }^{\circ} \mathrm{C}$ \\
\hline September & 33.8 & 13.9 & 73.3 & 12.1 & 40.4 & 13.2 \\
October & 65.1 & 6.3 & 2.7 & 5.5 & 32.2 & 8.3 \\
November & 40.4 & 5.0 & 113.0 & 4.5 & 31.4 & 3.0 \\
December & 35.7 & -1.3 & 39.5 & -6.4 & 31.9 & -0.5 \\
January & 22.0 & -2.0 & 33.0 & -0.9 & 24.2 & -2.3 \\
February & 20.1 & -1.7 & 14.9 & -4.4 & 19.2 & -1.6 \\
March & 29.8 & 1.8 & 11.6 & 2.7 & 24.7 & 1.8 \\
April & 31.7 & 7.6 & 12.6 & 10.2 & 27.3 & 7.4 \\
May & 90.6 & 12.8 & 37.8 & 13.5 & 43.1 & 13.0 \\
June & 18.1 & 16.1 & 100.4 & 17.5 & 54.3 & 16.2 \\
July & 109.4 & 18.0 & 130.8 & 17.4 & 71.2 & 18.0 \\
August & 17.5 & 17.6 & 68.4 & 17.8 & 54.1 & 17.5 \\
Sum/average & 514.2 & 8.5 & 638.0 & 8.1 & 453.3 & 8.5 \\
\hline
\end{tabular}

Moreover, relationships between the studied quality parameters were determined in conditions of the application of the preparations tested in the study.

The experiment was conducted during 2012-2014 using Muszelka cultivar (Triticum aestivum L. - winter wheat) from the Kuyavian-Pomeranian region in Noteć Valley, Poland $\left(53^{\circ} 12^{\prime} 24^{\prime \prime} \mathrm{N}, 17^{\circ} 51^{\prime} 40^{\prime \prime} \mathrm{E}\right)$. The soil in the experimental site has been classified by IUSS Working Group WRB as Haplic Luvisol (Cutanic), and characterized by the content of available $\mathrm{P}_{\text {Egner-Riehm }}$ and $\mathrm{K}_{\text {Egner-Riehm }}$ at the level of 173 and $180 \mathrm{mg} \mathrm{kg}^{-1} \mathrm{DM}$ (high content) respectively, and content of available $\mathrm{Mg}_{\text {Schachtschabel }}$ at the level $92.1 \mathrm{mg} \mathrm{kg}^{-1} \mathrm{DM}$ (very high content) and neutral reaction $\left(\mathrm{pH}_{\mathrm{KCl}}\right.$ 6.67). The experiment was laid out in randomized complete block design with four replications and the area of plots for harvest was $15 \mathrm{~m}^{2}$. Four stimulants and three combinations were used in the experiment (Table 1). Winter wheat was sown between 20 and 30 September.

Phosphorus and potassic fertilizers in the form of $46 \%$ triple superphosphate and $57 \%$ potassium salt (30 and
$70 \mathrm{~kg} \mathrm{ha}^{-1}$ ) were applied in autumn, before performing winter plowing. Fertilization with nitrogen $\left(120 \mathrm{~kg} \mathrm{ha}^{-1}\right)$ in the form of $34 \%$ ammonium nitrate was applied in spring $\left(60 \mathrm{~kg} \mathrm{ha}^{-1}\right.$ at the early vegetative phase, $60 \mathrm{~kg} \mathrm{ha}^{-1}$ at the shooting stage). Protective measures against weed infestation, pests and diseases were undertaken throughout the experimental period. Wheat grains were harvested at the full maturity stage (BBCH 92-99) in August.

Grain yield adjusted to constant humidity of $15 \%$ was recorded. Representative grain samples were collected from each plot for determination of quality parameters such as falling number (FN) according Hagberg method, protein content $(\mathrm{PC})$, wet gluten (WG), sedimentation value (SV) according Zeleny test and bread volume (BV). Falling number was determined in accordance with PNISO-3093. Three successive parameters (PC, WG, SV) were determined in whole-grain samples using a grain analyzer Infratec 1241 (Danmark, FOSS Analytical AB) which is capable of simultaneous determination of several constituents in whole-grain samples. Measurements are based on the fact that the main constituents in the grains absorb electromagnetic radiation in the near-infrared region of the spectrum. Values of the direct baking index (i.e. BV) were obtained after performing the single-phase baking process, according to the standard PN-A-74108.

The results obtained from the study were subjected to statistical analysis using ANOVA, and boundary differences were determined according to Tukey's test at significance level $P=0.05$. The results were also subjected to analysis of simple correlations and linear regression.

The weather conditions during the study period (20122014) were variable (Table 2). The amount and distribution of rainfall varied during the wheat growth period. In 2012-13, the total precipitation was higher than the longterm total by $60.9 \mathrm{~mm}$, and temperature was similar to the mean from 1949 to 2010. Spring and summer months (except June) were characterized by a higher amount of precipitation for this region, which in July 2013 exceeded the long-term total by as much as $38.2 \mathrm{~mm}$. The period 2013-14 was characterized by rainfall higher than average (by $34.7 \mathrm{~mm}$ ) and air temperature lower than the 


\section{RESEARCH COMMUNICATIONS}

Table 3. Grain yield and technological parameters of wheat after the application of stimulants

\begin{tabular}{|c|c|c|c|c|c|c|c|c|c|c|}
\hline \multirow[b]{2}{*}{ Parameter } & \multirow[b]{2}{*}{ Year } & \multicolumn{8}{|c|}{ Stimulants } & \multirow[b]{2}{*}{ Mean } \\
\hline & & $\mathrm{C}$ & A & B & $\mathrm{D}$ & $\mathrm{E}$ & $\mathrm{E}+\mathrm{A}$ & $E+D$ & $A+D$ & \\
\hline \multirow[t]{2}{*}{ GY $\left(\mathrm{t} \mathrm{ha}^{-1}\right)$} & 2013 & $5.30^{\mathrm{c}}$ & $5.90^{\mathrm{b}}$ & $5.61^{\mathrm{cb}}$ & $6.32^{\mathrm{a}}$ & $6.29^{\mathrm{a}}$ & $6.50^{\mathrm{a}}$ & $6.39^{\mathrm{a}}$ & $5.70^{\mathrm{b}}$ & 6.00 \\
\hline & 2014 & $5.76^{\mathrm{d}}$ & $6.37^{\mathrm{cb}}$ & $6.20^{\mathrm{c}}$ & $6.64^{\mathrm{b}}$ & $6.65^{\mathrm{ab}}$ & $6.92^{\mathrm{a}}$ & $6.73^{\mathrm{ab}}$ & $6.15^{\mathrm{c}}$ & 6.43 \\
\hline \multirow[t]{2}{*}{$\mathrm{FN}(\mathrm{s})$} & 2013 & $164^{\mathrm{b}}$ & $180^{\mathrm{a}}$ & $180^{\mathrm{a}}$ & $180^{\mathrm{a}}$ & $179^{\mathrm{a}}$ & $181^{\mathrm{a}}$ & $184^{\mathrm{a}}$ & $180^{\mathrm{a}}$ & 178 \\
\hline & 2014 & $251^{\mathrm{c}}$ & $266^{\mathrm{b}}$ & $285^{\mathrm{a}}$ & $288^{\mathrm{a}}$ & $287^{\mathrm{a}}$ & $286^{\mathrm{a}}$ & $291^{\mathrm{a}}$ & $287^{\mathrm{a}}$ & 280 \\
\hline \multirow[t]{2}{*}{$\mathrm{PC}\left(\mathrm{g} \cdot \mathrm{kg}^{-1}\right)$} & 2013 & $107^{\mathrm{c}}$ & $118^{\mathrm{b}}$ & $118^{\mathrm{b}}$ & $123^{\mathrm{a}}$ & $121^{\mathrm{ab}}$ & $120^{\mathrm{ab}}$ & $123^{\mathrm{a}}$ & $121^{\mathrm{ab}}$ & 119 \\
\hline & 2014 & $112^{\mathrm{d}}$ & $121^{\mathrm{c}}$ & $123^{\mathrm{bc}}$ & $127^{\mathrm{ab}}$ & $124^{\mathrm{bc}}$ & $123^{\mathrm{bc}}$ & $128^{\mathrm{a}}$ & $124^{\mathrm{bc}}$ & 123 \\
\hline \multirow[t]{2}{*}{ WG (\%) } & 2013 & $22.5^{\mathrm{g}}$ & $24.3^{\mathrm{e}}$ & $23.5^{\mathrm{f}}$ & $24.8^{\mathrm{cd}}$ & $26.5^{\mathrm{a}}$ & $26.0^{\mathrm{b}}$ & $25.1^{\mathrm{c}}$ & $24.8^{\mathrm{cd}}$ & 24.7 \\
\hline & 2014 & $25.7^{\mathrm{e}}$ & $27.6^{\mathrm{d}}$ & $26.9^{\mathrm{de}}$ & $28.1^{\mathrm{cd}}$ & $30.1^{\mathrm{a}}$ & $29.3^{\mathrm{ab}}$ & $28.8^{\mathrm{bc}}$ & $27.5^{\mathrm{d}}$ & 28.0 \\
\hline \multirow[t]{2}{*}{$\mathrm{SV}\left(\mathrm{cm}^{3}\right)$} & 2013 & $36.0^{\mathrm{e}}$ & $41.8^{\mathrm{ab}}$ & $39.0^{\mathrm{cd}}$ & $38.0^{\mathrm{de}}$ & $41.0^{\mathrm{bc}}$ & $44.0^{\mathrm{a}}$ & $42.0^{\mathrm{ab}}$ & $41.8^{\mathrm{ab}}$ & 40.4 \\
\hline & 2014 & $39.7^{\mathrm{g}}$ & $44.1^{\mathrm{d}}$ & $42.7^{\mathrm{e}}$ & $41.5^{\text {ef }}$ & $44.5^{\mathrm{cd}}$ & $47.8^{\mathrm{a}}$ & $46.3^{\mathrm{b}}$ & $45.6^{\mathrm{bc}}$ & 44.0 \\
\hline \multirow[t]{2}{*}{$\mathrm{BV}\left(\mathrm{cm}^{3}\right)$} & 2013 & $494^{\mathrm{f}}$ & $518^{\mathrm{e}}$ & $521^{\mathrm{d}}$ & $539^{\mathrm{ab}}$ & $530^{\mathrm{c}}$ & $529^{\mathrm{cd}}$ & $544^{\mathrm{a}}$ & $530^{\mathrm{c}}$ & 525 \\
\hline & 2014 & $503^{\mathrm{e}}$ & $530^{\mathrm{d}}$ & $547^{\mathrm{c}}$ & $558^{\mathrm{bc}}$ & $556^{\text {bc }}$ & $554^{\mathrm{bc}}$ & $570^{\mathrm{a}}$ & $559^{\mathrm{ab}}$ & 547 \\
\hline
\end{tabular}

C, Control; A, Amino acid preparation; B, Liquid fertilizer biostimulative active complex based on marine algae; D, Seaweed extract; E, Multiple natural foliar nanofertilizer; GY, Grain yield; FN, Falling number; PC, Total protein content; WG, Wet gluten content; SV, Sedimentation value; BV, Bread volume.

${ }^{a-g}$ Values followed by the same letter within particular rows are not significantly different at the 0.05 level according to the Tukey's test.

long-term mean by $0.4^{\circ} \mathrm{C}$. The total precipitation in June 2011 exceeded almost two times the long-term average, which amounted to $54.3 \mathrm{~mm}$.

Grain yield of winter wheat varied during the study period (Table 3); in 2014, it was $7.2 \%$ higher than in 2013. The lowest grain yield was obtained in 2013, when in June the conditions were extremely dry (mainly due to rainfall deficit). The relationships worked out confirm the effect of climatic conditions during the growth period on wheat grain yield as reported by other researchers ${ }^{12,14,35-38}$. Deficit rainfall at earing, flowering and grain filling stages showed a negative effect on grain yield and its quality ${ }^{39}$. Wheat grain yield was determined by the application of growth stimulants (Table 3). Multiple natural foliar nanofertilizer + amino acid preparation recorded higher grain yield by $22.6 \%$ and $20.1 \%$ during 2013 and 2014 respectively, compared to control. Experimental evidence showed, as reported by Dromantiene et $a l^{40}$, that winter wheat grain yield increased by $0.13-0.37 \mathrm{t} \mathrm{ha}^{-1}(0.10$ $6.04 \%$ ) with the application of amino acid preparation. The amino acids promote development of the root system and activate growth of the above-ground plant parts. Experiments showed that the amino acids, which were used for plant fertilization, promoted plant respiration, photosynthesis, water cycle as well as plant growth and yield. Besides, amino acids in the plants make chelate combination with the macro- and microelements, especially with microelements ${ }^{41-44}$. According Masilionyte and Maikštenienè $\dot{~}^{45}$, very intense cell division and metabolism of protein and biologically active substances in Poaceae plants occur during the heading stage under favourable moisture regime and mineral nutrition. Therefore, it is likely that during this stage, the liquid amide nitrogen fertilizers with amino acids and foliar nanofertilizers with mineral elements tend to activate physiological processes which occur in the cells of winter wheat and also increase the grain yield. Significantly higher grain yield compared with control, from $6.8 \%$ to $20.6 \%$, was also observed for the other experimental treatments (except for liquid fertilizer biostimulative in 2013). The positive effect of stimulants (Fertigrain, abscisic acid, Plonvit Active, Kelpak SL, Fertileader Vital-954) on wheat grain yield has been reported in several studies ${ }^{13,25-27,29,35,46,47}$.

Falling number is the trait from which the evaluation of grain baking quality should begin (results above the standard, i.e. 175-200 s, may indicate that the grain does not meet consumption requirements). In 2013 and 2014, the studied material was characterized by falling number values on average at the level 178 and 278 s (Table 3), in contrast to high values found in other studies ${ }^{3,4,6,11,48}$. The stimulants used in the study had a marked influence on falling number and its values were significantly higher in comparison with control; the highest value was obtained with the treatment where multiple natural foliar nanofertilizer and seaweed extract were applied in combination $(E+D)$. According to earlier studies, the falling number is affected by weather and genetic properties of the culti$\operatorname{var}^{6,9,49}$

An important criterion of evaluation of wheat baking quality is protein content, which is genetically determined, but to a great extent modified by the cultivation technology and environmental factors ${ }^{7,9,10}$. In wheat grain it amounts to $78-174 \mathrm{~g} \mathrm{~kg}^{-1} \mathrm{DM}^{3,4,8,16,50}$. Protein content in the grains of the studied cultivar was not very high (Table 3 ). The applied preparations significantly determined protein content in grain, obtaining higher values in comparison with control, from $10.3 \%$ to $15.0 \%$ in 2013 and $8.0 \%$ to $14.3 \%$ in 2014 . The highest protein content was obtained after the application of multiple natural foliar nanofertilizer + seaweed extract and slightly 
RESEARCH COMMUNICATIONS

Table 4. Correlation between the features of wheat

\begin{tabular}{|c|c|c|c|c|c|c|c|c|c|c|c|c|}
\hline \multirow{2}{*}{ Parameter } & GY & FN & $\mathrm{PC}$ & WG & SV & BV & GY & FN & $\mathrm{PC}$ & WG & SV & BV \\
\hline & \multicolumn{3}{|c|}{$\mathrm{C}$} & \multicolumn{3}{|c|}{ A } & \multicolumn{3}{|c|}{ B } & \multicolumn{3}{|c|}{ D } \\
\hline$\overline{\mathrm{GY}}$ & - & $* * *$ & $* *$ & $* * *$ & $* * *$ & $* * *$ & - & $* * *$ & $* * *$ & $* * *$ & $* *$ & $* * *$ \\
\hline FN & $* * *$ & - & $* *$ & $* * *$ & $* * *$ & $* * *$ & $* * *$ & - & $* * *$ & $* * *$ & $* * *$ & $* * *$ \\
\hline $\mathrm{PC}$ & $* * *$ & $* * *$ & - & $* * *$ & $*$ & $* * *$ & $* * *$ & $* * *$ & - & $* * *$ & $* * *$ & $* * *$ \\
\hline WG & $* * *$ & $* * *$ & $* * *$ & - & $* * *$ & $* * *$ & $* * *$ & $* * *$ & $* * *$ & - & $* * *$ & $* * *$ \\
\hline SV & $* * *$ & $* * *$ & $* * *$ & $* * *$ & - & $* * *$ & $* *$ & $* * *$ & $* * *$ & $* * *$ & - & $* * *$ \\
\hline BV & $* *$ & $*$ & n.s. & $* *$ & $*$ & - & $* * *$ & $* * *$ & $* * *$ & $* * *$ & $* * *$ & - \\
\hline \multicolumn{4}{|l|}{$\overline{\mathrm{E}}$} & \multicolumn{3}{|c|}{$E+A$} & \multicolumn{3}{|c|}{$E+D$} & \multicolumn{3}{|c|}{$A+D$} \\
\hline$\overline{\mathrm{GY}}$ & - & $* *$ & $*$ & $* * *$ & $*$ & $* *$ & - & $* * *$ & * & $* * *$ & $* * *$ & $* * *$ \\
\hline $\mathrm{FN}$ & $* * *$ & - & $*$ & $* * *$ & $* * *$ & $* * *$ & $* * *$ & - & $*$ & $* * *$ & $* * *$ & $* * *$ \\
\hline $\mathrm{PC}$ & $* * *$ & $* * *$ & - & $* * *$ & $* * *$ & $*$ & $* * *$ & $* * *$ & - & $* * *$ & $* * *$ & $*$ \\
\hline WG & $* * *$ & $* * *$ & $* * *$ & - & $* * *$ & $* * *$ & $* * *$ & $* * *$ & $* * *$ & - & $* * *$ & $* * *$ \\
\hline SV & $* * *$ & $* * *$ & $* *$ & $* * *$ & - & $* * *$ & $* * *$ & $* * *$ & $* * *$ & $* * *$ & - & $* * *$ \\
\hline BV & $* * *$ & $* * *$ & $*$ & $* * *$ & $* * *$ & - & $* *$ & $* * *$ & $* *$ & $* * *$ & $* *$ & - \\
\hline
\end{tabular}

*,** and ***Significant at $P<0.01 ; 0.05$ and 0.001 probability levels respectively; ns, Non significant.

smaller after the application of multiple natural foliar nanofertilizer and combination of amino acid preparation + seaweed extract. The increase in protein content in wheat grain and control after the application of preparations Kelpak SL, Plonvit Active and Fertileader Vital-954, has been reported earlier ${ }^{35,46,47}$. Averaged data showed that the amino acid fertilizers significantly increased protein content in winter wheat grain (by $0.62-0.81$ percentage points $)^{40}$.

Akçura ${ }^{1}$ observed a positive correlation between protein content and sedimentation value, and a negative correlation between protein content and grain yield. However, in the study by Knapowski et al. ${ }^{7}$, this feature was negatively correlated with grain yield, falling number, wet gluten content and sedimentation value, which does not correspond with the results of other studies ${ }^{49}$ and confirmed in the present study (the highest for seaweed extract and amino acids preparation treatment) (Table 4). The gluten content statistically significantly correlated with protein content in grain in a study by Dromantiene et $a l .^{40}$. Grain from the treatments where stimulants were used (except for amino acid preparation and liquid fertilizer biostimulative in 2013) may be classified as bread wheat (boundary values $\left.120-124 \mathrm{~g} \mathrm{~kg}^{-1}\right)^{51}$.

The baking quality of wheat flour is largely determined by the amount and quality of gluten. Wet gluten is composed of gliadins and glutenins, which are involved in the formation of the dough structure and then the bread. In 2013 and 2014 wet gluten of grain reached on average $24.7 \%$ and $28.0 \%$ level (Table 3); it was lower than the result of Matus et al. ${ }^{3,4}$, and higher than those reported by Stępien et al. ${ }^{8}$ and Sirbu et al. ${ }^{27}$. The amount of wet gluten in grain was significantly dependent on the stimulant applied. The highest values in 2013 and 2014 were observed for the treatments multiple natural foliar nanofertilizer $(26.5 \%$ and $31.0 \%)$ and multiple natural foliar nanofertilizer + amino acid preparation $(26.0 \%$ and $29.3 \%$ ) respectively; these were higher in comparison with control and liquid fertilizer biostimulative by $3.9 \%$ and $3.4 \%$ as well as $3.0 \%$ and $2.5 \%$ respectively. The amount of wet gluten for experimental treatments (except $B$ in 2014) reached statistical significance in relation to control. Positive effect of stimulants on the amount of wet gluten has been reported in earlier studies ${ }^{27,46}$. Panayotova et al. ${ }^{47}$ confirmed the favourable effect of liquid fertilizer biostimulative, and Matysiak et al. ${ }^{35}$ of seaweed extract, on this feature, but only in the year when spring was a period of drought or semi-drought (similar to the second year of the present study). According to averaged data of 2007-09 in a study by Dromantiene et al. ${ }^{40}$, it could be claimed that the amino acids increase the content of wet gluten in the grain of winter wheat (the best results at $30.7-31.3 \%$ ).

Sedimentation value is the baking index which characterizes the amount and quality of protein complex determining the bread structure. Stimulants (except for seaweed extract in 2013) significantly increased flour sedimentation value compared with control (from 5.6\% to $22.2 \%$ in 2013 and $4.5 \%$ to $20.4 \%$ in 2014 ) (Table 3 ). The flour obtained from the treatment with applied multiple natural foliar nanofertilizer + amino acid preparation $\left(44 \mathrm{~cm}^{3}-2013\right.$ and $\left.47.8 \mathrm{~cm}^{3}-2014\right)$ was characterized by the highest sedimentation value; it was higher not only in relation to control, but also in comparison with those treatments liquid fertilizer biostimulatant, seaweed extract and multiple natural foliar nanofertilizer in 2013, and from all the treatments in 2014. In respect of the sedimentation value, according to Podolska and Sułek ${ }^{51}$, grain harvested from all the experimental treatments can be classified as the wheat quality class.

A direct quality indicator which demonstrates the baking value of wheat grain is the bread volume from test 


\section{RESEARCH COMMUNICATIONS}

baking. The stimulants applied in the experiment resulted in a significant increase in bread volume obtained from $100 \mathrm{~g}$ flour of cv. Muszelka, compared with control. The highest values in 2013 and 2014 (544 and $570 \mathrm{~cm}^{3}$ respectively) were obtained for the treatment multiple natural foliar nanofertilizer + seaweed extract and slightly lower for seaweed extract (Table 3). Similar to the study by Knapowski et al. ${ }^{11}$, bread volume was significantly positively correlated with grain yield, falling number, protein content, wet gluten and the sedimentation value (Table 4). Positive relationships of bread volume with wet gluten and sedimentation value were also reported by Ralcewicz et al. ${ }^{49}$. The obtained results allowed the calculation of linear regression equations. They indicate that an increase in protein content in grain after application of seaweed extract, multiple natural foliar nanofertilizer, multiple natural foliar nanofertilizer + amino acid preparation and multiple natural foliar nanofertilizer + seaweed extract, say by $10 \mathrm{~g} \mathrm{~kg}^{-1} \mathrm{DM}$, may increase the amount of wet gluten in grain by: $5.88 \% ; 8.09 \% ; 6.02 \%$ and $5.93 \%$

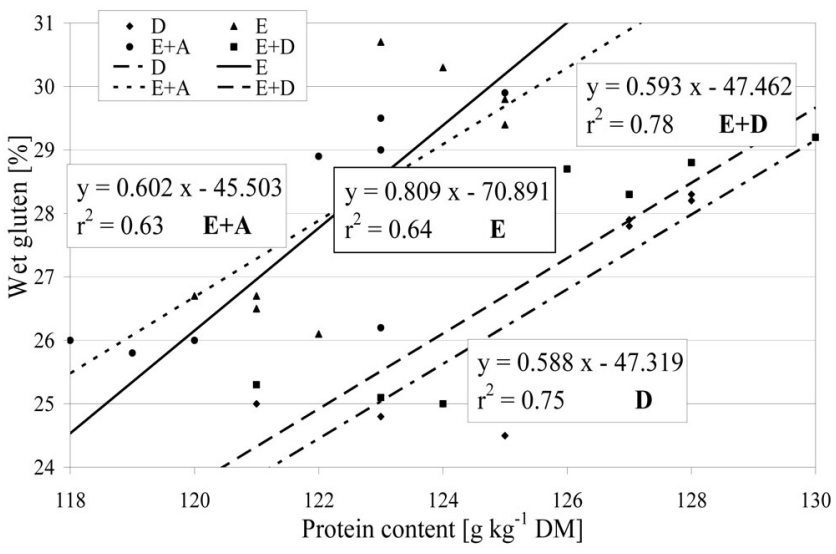

Figure 1. Relationships between protein content and content of wet gluten of winter wheat treated using different stimulants and their combinations. C, Control; A, Amino acid preparation; B, Liquid fertilizer biostimulative active complex based on marine algae; D, Seaweed extract; E, Multiple natural foliar nanofertilizer,

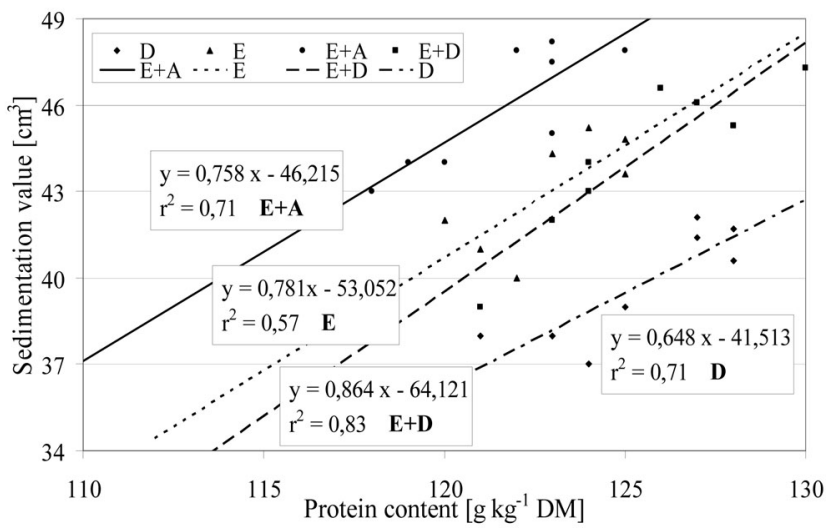

Figure 2. Relationships between protein content and sedimentation value of winter wheat treated using different stimulants and their combinations. respectively (Figure 1), and sedimentation value of flour by $6.48,7.81,7.58$ and $8.64 \mathrm{~cm}^{3}$ respectively (Figure 2). The above relationships were confirmed in other studies as well ${ }^{11,49}$.

Foliar application of all stimulating preparations and fertilizers causes an increase in winter wheat grain yield compared with the control. The highest significant value was obtained after the application of multiple natural foliar nanofertilizer in combination with amino acid preparation (higher by $22.6 \%$ and $20.1 \%$ respectively for 2013 and 2014 compared to control). It is likely that liquid amino acid preparation and foliar nanofertilizers with mineral elements activate the physiological processes that occur in the cells of winter wheat and also increase the grain productivity. The most favourable values of technological traits, in turn, were obtained after the application of multiple natural foliar nanofertilizer in combination with seaweed extract or amino acid preparation (except for wet gluten content, which was the highest after spraying the plantation with multiple natural foliar nanofertilizer). Combined application of multiple natural foliar nanofertilizer and seaweed extract had the most favourable effect on grain yield and the studied features of winter wheat grain and flour. The interest in multiple natural foliar nanofertilizer and preparations stimulating plant growth and development is constantly increasing, it may become one of the essential elements of cultivation technology in future. Broadening the knowledge on bioregulators can help increase agricultural and horticultural production. Agricultural biostimulants may contribute to making agriculture more sustainable and resilient, and offer an alternative to synthetic protectants which have been increasingly falling out of favour among consumers. Therefore, there is a need for further studies of their applications in agriculture.

1. Akçura, M., The relationships of some traits in Turkish winter bread wheat landraces. Turk. J. Agric. For., 2011, 35, 115-125.

2. Denčić, S., Mladenov, N. and Kobiljski, B., Effects of genotype and environment on breadmaking quality in wheat. Int. J. Plant Prod., 2011, 5, 71-82.

3. Matus, I., Madariaga, R., Jobet, C., Zúñiga, J. and Alfaro, Ch., Kipa-INIA, new high yield spring bread wheat variety for Chile. Chil. J. Agric. Res., 2011, 71, 323-328.

4. Matus, I., Madariaga, R., Jobet, C., Zúñiga, J. and Alfaro, Ch., Millan-INIA, new variety of high quality early spring bread wheat for irrigated soils in central-southern Chile. Chil. J. Agric. Res., 2011, 71, 329-332.

5. Ram, H. et al., Agronomic fortification of rice and wheat grains with zinc for nutritional security. Curr. Sci., 2014, 109(6), 11711176.

6. Silva, R. R., Benin, G., de Almeida, J. L., de Batista Fonseca, I. C. and Zucareli, C., Grain yield and baking quality of wheat under different sowing dates. Acta Sci. Agron., 2014, 36, 201-210.

7. Knapowski, T., Szczepanek, M., Wilczewski, E. and Pobereżny, J., Response of wheat to seed dressing with humus and foliar potassium fertilization. J. Agric. Sci. Technol., 2015, 17, 1559-1569.

8. Stępień, A., Wojtkowiak, K., Orzech, K. and Wiktorski, A., Nutritional and technological characteristics of common and spelt 
wheat are affected by mineral fertilizer and organic stimulator NANO-GRO ${ }^{\circledR}$. Acta Sci. Pol., Agric., 2016, 15, 49-63.

9. Kozlovský, O., Balík, J., Černý, J., Kulhánek, M., Kos, M. and Prášilová, M., Influence of nitrogen injection (CULTAN) on yield, yield components formation and quality of winter wheat grain. Plant Soil Environ., 2009, 55, 536-543.

10. Campillo, R., Jobet, C. and Undurraga, P., Effects of nitrogen on productivity, grain quality, and optimal nitrogen rates in winter wheat cv. Kumpa-INIA in andisols of southern Chile. Chil. J. Agric. Res., 2010, 70, 122-131.

11. Knapowski, T., Spychaj-Fabisiak, E. and Ložek, O., Foliar nitrogen fertilization as a factor determining technological parameters of winter wheat. Ecol. Chem. Eng. A, 2010, 17, 771-779.

12. Benin, G., Bornhofen, E., Beche, E., Pagliosa, E. S., Lemes da Silva, C. and Pinnow, C., Agronomic performance of wheat cultivars in response to nitrogen fertilization levels. Acta Sci. Agron., 2012, 34, 473-479.

13. Mohammadi, H., Ahmadi, A., Yang, J. C., Moradi, F., Wang, Z., Abbasi, A. and Poustini K., Effects of nitrogen and ABA application on basal and distal kernel weight of wheat. J. Agric. Sci. Technol., 2013, 15, 889-900.

14. Liu, J., Wang, G., Kelly, T., Zhang, Y., Yang, M. and Chu, Q., Effect of nitrogen and water deficit type on the yield gap between the potential and attainable wheat yield. Chil. J. Agric. Res., 2015, 75, 457-464.

15. Sangeeta, L. and Singh, A. K., Simulating interactive effect of irrigation and nitrogen on crop yield and water productivity in maize-wheat cropping system. Curr. Sci., 2011, 101, 1451-1461.

16. Zodape, S. T., Mukherjee, M. P., Reddy, D. R. and Chaudhary, D. R., Effect of Kappaphycus alvarezii (Doty) Doty ex silva extract on grain quality, yield and some yield components of wheat (Triticum aestivum L.). Int. J. Plant Prod., 2009, 3, 97-101.

17. Shaaban, M. M., El-Saady, A. M. and El-Sayed, A. B., Green microalgae water extract and micronutrients foliar application as promoters to nutrient balance and growth of wheat plants. $J$. Am. Sci., 2010, 6, 631-636.

18. Shah, M. T., Zodape, S. T., Chaudhary, D. R., Eswaran, K. and Chikara, J., Seaweed sap as an alternative liquid fertilizer for yield and quality improvement of wheat. J. Plant Nutr., 2013, 36, 192200.

19. Szczepanek, M. and Grzybowski, K., Yield and macronutrient accumulation in grain of spring wheat (Triticum aestivum ssp. vulgare L.) as affected by biostimulant application. Adv. Crop Sci. Technol., 2016, 4, 1-4.

20. Van Oosten, M. J., Pepe, O., De Pascale, S., Silletti, S. and Maggio, A., The role of biostimulants and bioeffectors as alleviators of abiotic stress in crop plants. Chem. Biol. Technol. Agric., 2017, 4, $1-12$.

21. Sharma, S. H., Fleming, C., Selby, Ch., Rao, J. R. and Trevor, M., Plant biostimulants: a review on the processing of macroalgae and use of extracts for crop management to reduce abiotic and biotic stresses. J. Appl. Phycol., 2014, 26, 465-490.

22. Halpern, M., Bar-Tal, A., Ofek, M. and Minz, D., The use of biostimulants for enhancing nutrient uptake. Adv. Agron., 2015, 130, 141-174.

23. Khan, W. et al., Seaweed extracts as biostimulants of plant growth and development. J. Plant Growth Regul., 2009, 28, 386-399.

24. Craigie, J. S., Seaweed extract stimuli plant science and agriculture. J. Appl. Phycol., 2011, 23, 371-393.

25. Al Majathoub, M., Effect of biostimulants on production of wheat (Triticum aestivum L.). In Mediterranean Rainfed Agriculture: Strategies for Sustainability (eds Cantero-Martinez, C. and Gabina, D.), CIHEAM (Options Mediterraneennes: Serie A), 2004, pp. $147-150$.

26. Matysiak, K. and Adamczewski, K., Influence of bioregulator Kelpak on yield of cereals and other crops. Prog. Plant Prot., 2006, 46, 102-108.
27. Sirbu, C., Cioroianu, T. M., Cojoraru, I., Trandafir, V. and Albu, M. G., Fertilizers with protein chelated structures with biostimulator role. Rev. Chim., 2009, 60, 1135-1140.

28. Khan, A. S., Ahmad, B., Jaskani, M. J., Ahmad, R. and Malik, A. U., Foliar application of mixture of amino acids and seaweed (Ascophylum nodosum) extract improve growth and physicochemical properties of grapes. Int. J. Agric. Biol., 2012, 14, 383388.

29. Sevov, A. and Delibaltova, V., Effect of biostimulant fertigrain on bread wheat (Triticum aestivum) productivity elements and grain yield. Sci. Pap. A. Agron., 2013, 56, 353-356.

30. Stirk, W., Tarkowska, D., Turecova, V., Strand, M. and van Staden, J., Abscisic acid, gibberellins and brassinosteroids in Kelpak and commercial seaweed extract made from Ecklonia maxima. $J$. Appl. Phycol., 2014, 26, 561-567.

31. Stirk, W. A. and van Staden, J., Plant growth regulators in seaweeds: occurrence regulation and functions. Adv. Bot. Res., 2014, 71, 125-159.

32. Kurepin, L. V., Zaman, M. and Pharis, R. P., Phytohormonal basis for the plant growth promoting action of naturally occurring biostimulators. J. Sci. Food Agric., 2014, 94, 1715-1722.

33. Papenfus, H. B., Kulkarni, M. G., Stirk, W. A., Finnie, J. F. and van Staden, J., Effect of a commercial seaweed extract $\left(\operatorname{Kelpak}^{\circledR}\right)$ and polyamines on nutrient-deprived (N, P and $\mathrm{K}$ ) okra seedlings. Sci. Hortic., 2013, 151, 142-146.

34. Kumar, G. and Sahoo, D., Effect of seaweed liquid extract on growth and yield of Triticum aestivum var. Pusa Gold. J. Appl. Phycol., 2011, 23, 251-255.

35. Matysiak, K., Kaczmarek, S. and Leszczyńska, D., Influence of liquid seaweed extract of Eclonia maxima on winter wheat cv. Tonacja. J. Res. Appl. Agric. Eng., 2012, 57, 44-47.

36. Najafian, G., Kaffashi, A. K. and Jafar-Nezhad, A., Analysis of grain yield stability in hexaploid wheat genotypes grown in temperate regions of Iran using additive main effects and multiplicative interaction. J. Agric. Sci. Technol., 2010, 12, 213-222.

37. Jug, I., Jug, D., Sabo, M., Stipešević, B. and Stošić, M., Winter wheat yield components as affected by soil tillage systems. Turk. J. Agric. For., 2011, 35, 1-7.

38. Tadayon, M. R., Ebrahimi, R. and Tadayon, A., Increased water productivity of wheat under supplemental irrigation and nitrogen application in a semi-arid region. J. Agric. Sci. Technol., 2012, 14, 995-1003.

39. Woźniak, A. and Staniszewski, M., The influence of weather conditions on grain quality of spring wheat $\mathrm{cv}$. Opatka and winter wheat cv. Korweta. Acta Agrophys., 2007, 9, 525-540.

40. Dromantienė, R., Pranckietienè, I., Šidlauskas, G. and Pranckietis, V., Changes in technological properties of common wheat (Triticum aestivum L.) grain as influenced by amino acid fertilizers. Zemdirbyste-Agriculture, 2013, 100, 57-62.

41. Nikiforova, V. J. et al., Effect of sulfur availability on the integrity of amino acid biosynthesis in plants. Amino Acids, 2006, 30, 173-183; http://dx.doi.org/10.1007/s00726-005-0251-4

42. Alaru, M., Laur, U. and Jaama E., Influence of nitrogen and weather conditions on the grain quality of winter triticale. Agron. Res., 2003, 1, 3-10.

43. Meijer, A. J., Amino acids as regulators and components of nonproteinogenic pathways. J. Nutr., 2003, 9, 2057-2062.

44. Azevedo, R. A., Lancien, M. and Lea, P. J., The aspartic acid metabolic pathway, an exciting and essential pathway in plants. Amino Acids, 2006, 30, 143-162; http://dx.doi.org/10.1007/s00726-005$\underline{0245-2}$

45. Masilionyte, L. and Maikštennienė, S., The effect of agronomic and climatic factors on the accumulation of nutrients in the yield of main and catch crops. Zemdirbyste-Agriculture, 2011, 98(3), 235244.

46. Farcaş, N., Groza, O., Dobre, P., Moraru, A. C., Simion, C. O. and Simion, M., Research concerning the behavior of fall wheat upon 
fertilization with plonvit active. Rom. Biotechnol. Lett., 2014, 19, 9510-9516.

47. Panayotova, G. D., Bozhanova, V. Z., Kostadinova, S. S., Valkova, N. K. and Almaliev, M., Response of durum wheat (Triticum durum Desf.) cultivar progress to foliar feeding. Agric. Food, 2014, 2, 288-297.

48. Bulut, S., Öztürk, A., Karaoğlu, M. M. and Yildiz, N., Effects of organic manures and non-chemical weed control on wheat. II. Grain quality. Turk. J. Agric. For., 2013, 37, 271-280.

49. Ralcewicz, M., Knapowski, T., Kozera, W. and Barczak, B., Technological value of 'Zebra' spring wheat depending on the nitrogen and magnesium application method. J. Cent. Eur. Agric., 2009, 10, 223-232.

50. Biel, W. and Maciorkowski, R., Assessing nutritional value of grains of selected wheat cultivars. Food Sci. Technol. Qual., 2012, 2, 45-55.

51. Podolska, G. and Sułek, A., Quality of wheat grain produced in Poland and the UE. Pam. Put., 2003, 132, 363-369.

ACKNOWLEDGEMENTS. Publication carried out with the use of instruments bought in the framework of programme 'Development of Stage 2 of Regional Centre for Innovativeness' the European Fund for Regional Development in the framework of the Regional Operation Programme of Kuyavian-Pomeranian for 2007-13.

\section{Challenges of hill farming due to crop-raiding by wild pigs in the Indian Himalayan region}

\author{
Latika Pandey $^{1, *}$, Ayyanadar Arunachalam ${ }^{1}$ and \\ Namita Joshi ${ }^{2}$ \\ ${ }^{1}$ Task Force on Himalayan Agriculture, Indian Council of Agricultural \\ Research, Krishi Anusandhan Bhawan-II, New Delhi 110 012, India \\ ${ }^{2}$ Gurukul Kangri Vishwavidyalaya, Haridwar, Jagjeetpur, \\ Haridwar 249 404, India
}

The human societies living in the Himalayas are traditionally known for their symbiotic relationship with their surrounding ecosystem. With changing time and climatic conditions, this relationship is also transforming. One of the crucial examples of this transformation is the interaction between human and wild animals, that a few of the Himalayan villages have moved from 'co-sustenance' to 'conflict'. The agribased villages situated adjoining the forest area are experiencing recurrent incidences of crop raiding by wild pigs. These raidings have emerged out as a noticeable threat to the existing agrobiodiversity of the area. Hence, plausible solutions to keep away the

*For correspondence. (e-mail: latikalata237@gmail.com) crop raiders with special emphasis on the wild pigs are the need of the hour.

Keywords: Agriculture, crop raiding, Himalayas, wild pig.

RECENT years have witnessed increasing incidences of human and wild animal conflicts, particularly in those villages that are neighbouring wilderness ${ }^{1,2}$. Reportedly, blackbuck in Gujarat has caused a loss of $48,600 \mathrm{~kg}$ of sorghum in a single season in two villages worth Rs $29,000$ (US $\$ 558)^{3}$. From carnivores like leopard and tiger that have wider habitat range to the smaller ones including wild pigs, porcupine, rabbits, mice and rats cause damage to human upon sudden encounters ${ }^{4-6}$. In the plains of Uttarakhand, other than wild pig (Sus scrofa), there are animals which damage crops like sambhar (Rusa unicolor), nilgai (Boselaphus tragocamelus), cheetal (Axis axis) and elephant (Elephas maximus). Of these, wild pig and nilgai enter the fields which are farther from the forest ${ }^{7}$. A case study of Bilaspur district of Sutluj valley in the outer hills of the Himalaya depicted that the major menace for crop depredation was wild rhesus macaque, followed by wild pig and then rodents. The study also reported a considerable increase in weed population like Anagallis arvensis and Lantana camara ${ }^{8}$.

The Himalayan agro-ecosystems are vulnerable to man-animal interface that cause causalities as well as crop damage. In our efforts to reduce man-animal conflict, particularly in vulnerable areas, it is important to take stock of the site characteristics and human vulnerabilities and understand the dynamics and challenges in doing agriculture under exorbitant threats posed by the crop-raiders. We surveyed two villages in the forested neighbourhood of Almora district in Uttarakhand and documented the crop raiders and their impact on cropping systems.

The present study was carried out in two adjacent villages, Dantola $\left(29^{\circ} 51.266^{\prime} \mathrm{N}\right.$ and $\left.79^{\circ} 22.962^{\prime} \mathrm{E}\right)$ and Mahatgaon $\left(29^{\circ} 51.608^{\prime} \mathrm{N}\right.$ and $\left.79^{\circ} 22.507^{\prime} \mathrm{E}\right)$ of Kumaun Himalaya in the Almora district of Uttarakhand where the altitude ranges from 1010 to $1106 \mathrm{~m}$. The region receives an annual rainfall of $862.8 \mathrm{~mm}$. Agriculture is the backbone of the region, as more than $50 \%$ of the people are dependent on it for sustaining their livelihood. Total forest cover of the district is $1583 \mathrm{sq} . \mathrm{km}$ which is around $50 \%$ of the total area of the district ( 3144 sq. km), indicating the importance of forests in the lives of hill people? .

Both the villages are situated adjoining the forest area. Hence many wild animals like leopard, wild pigs, deer, fox, apes and monkeys are often found roaming in the villages. Leopard, deer and wild boar are generally seen at nights, while the monkeys and apes are abundant during day time in these villages. Fox are also seen anytime of the day. Villagers traditionally visit the forest to 